Sains Malaysiana 50(3)(2021): 829-837

http://dx.doi.org/10.17576/jsm-2021-5003-23

\title{
Comparative Evaluation of the Effects of Atorvastatin and Lovastatin on the Pharmacokinetics of Aliskiren in Rats
}

(Penilaian Perbandingan Kesan Atorvastatin dan Lovastatin terhadap Farmakokinetik Aliskiren pada Tikus)

\author{
Amal Sharaf, Kamal A. El-Shazly, Amera Abd El latif, Khaled S. AbdelKawy, Fawzy Elbarbry \& \\ HAZIM O. KHALIFA*
}

\begin{abstract}
The worldwide increase in the number patients with high blood pressure poses serious clinical challenges. Little is known regarding the interactions between the various drugs used to treat heart diseases. The present study evaluates and compares the effects of administration of multiple doses of atorvastatin or lovastatin on the pharmacokinetics of aliskiren in rats in an effort to determine their underlying mechanisms. A total of 90 healthy female albino rats were randomly divided into three groups. All groups were treated with aliskiren by oral gavage at $8.57 \mathrm{mg} / \mathrm{kg}$ daily for 14 days. In addition to aliskiren, group 2 received atorvastatin at a dose of $1.143 \mathrm{mg} / \mathrm{kg}$ for 7 days. In addition to aliskiren, group 3 received lovastatin at a dose of $1.143 \mathrm{mg} / \mathrm{kg}$ for 7 days. After blood samples were collected at specific time intervals, aliskiren concentrations were determined using liquid chromatography-tandem mass spectrometry. Relative to the control treatment, atorvastatin treatment resulted in non-significant alterations in the pharmacokinetic parameters of aliskiren. In contrast, lovastatin resulted in a significant increase in the area under the curve, peak plasma concentration, and elimination half-life by 21, 10, and 72\%, respectively. Additionally, lovastatin significantly reduced oral clearance by $23 \%$. Inhibition of aliskiren metabolism via the hepatic CYP3A subfamily and/or inhibition of intestinal P-glycoprotein and/or the CYP3A subfamily was identified as a possible mechanism. This study is the first to report that only lovastatin causes a marked increase in aliskiren bioavailability. Caution should be taken when lovastatin and aliskiren are administrated concomitantly in clinical practice.
\end{abstract}

Keywords: Coronary artery disease; drug interactions; high blood pressure; statins

\section{ABSTRAK}

Peningkatan jumlah pesakit darah tinggi di seluruh dunia menimbulkan cabaran klinikal yang serius. Tidak banyak yang diketahui mengenai interaksi antara pelbagai dadah yang digunakan untuk merawat penyakit jantung. Kajian ini menilai dan membandingkan kesan pemberian pelbagai dos atorvastatin atau lovastatin terhadap farmakokinetik aliskiren pada tikus dalam usaha untuk menentukan mekanisme asasnya. Sebanyak 90 tikus albino betina yang sihat dibahagikan secara rawak kepada tiga kumpulan. Semua kumpulan dirawat dengan aliskiren dengan pemberian oral sebanyak $8.57 \mathrm{mg} / \mathrm{kg}$ setiap hari selama 14 hari. Sebagai tambahan kepada aliskiren, kumpulan 2 menerima atorvastatin pada dos $1.143 \mathrm{mg} / \mathrm{kg}$ selama 7 hari. Sebagai tambahan kepada aliskiren, kumpulan 3 menerima lovastatin pada dos $1.143 \mathrm{mg} / \mathrm{kg}$ selama 7 hari. Setelah sampel darah dikumpulkan pada selang waktu tertentu, kepekatan aliskiren ditentukan menggunakan spektrometri jisim kromatografi cair-tandem. Berkaitan dengan rawatan kawalan, rawatan atorvastatin mengakibatkan perubahan yang tidak ketara pada parameter farmakokinetik aliskiren. Sebaliknya, lovastatin menghasilkan peningkatan yang signifikan di kawasan di bawah kurva, kepekatan plasma puncak dan penghilangan separuh hayat masing-masing sebanyak 21, 10 dan 72\%. Selain itu, lovastatin mengurangkan pelepasan oral dengan ketara sebanyak 23\%. Sebaliknya, lovastatin menghasilkan peningkatan yang signifikan di kawasan di bawah kurva, kepekatan plasma puncak, dan penghilangan separuh hayat masing-masing sebanyak 10, 21 dan $72 \%$. Selain itu, lovastatin mengurangkan pelepasan oral dengan ketara sebanyak 23\%. Perencatan metabolisme aliskiren melalui subfamili CYP3A hepatik dan/atau perencatan P-glikoprotein usus dan/atau subfamili CYP3A dikenal pasti sebagai mekanisme yang berkemungkinan. Kajian ini adalah yang pertama melaporkan bahawa hanya lovastatin yang menyebabkan peningkatan bioavailabiliti aliskiren yang ketara. Perhatian harus diambil ketika lovastatin dan aliskiren diberikan bersamaan dalam praktik klinikal.

Kata kunci: Interaksi dadah; penyakit arteri koronari; statin; tekanan darah tinggi 


\section{INTRODUCTION}

High blood pressure is a common and dangerous condition affecting approximately 75 million people in the US alone (Merai et al. 2016). Hypertension increases the risk of heart disease and stroke (Yoon et al. 2015). The American Heart Association estimates that the total cost of treating hypertension in the US in 2030 will be \$200225 billion (Benjamin et al. 2017), with $45 \%$ of the direct cost of treating hypertension being related to medication (Merai et al. 2016). Aliskiren, an orally bioavailable direct renin inhibitor, was recently approved for the treatment of hypertension (Wood et al. 2003). Aliskiren shows poor absorption, with oral bioavailability of only $2.5 \%$ (Zhao et al. 2006). Recently, aliskiren proved to be effective and safe for severe coronavirus disease 2019 (COVID-19) patients with hypertension (Guo et al. 2020). Furthermore, aliskiren displayed higher binding energies than aliskiren co-crystallized ligand N3 with COVID-19 main protease (Omar 2020). This improves its renin inhibition advantage and the possibility of reduced expression of angiotensin-converting enzyme 2 (Mourad \& Levy 2020). The plasma protein binding of aliskiren is $50 \%$, with an apparent volume of distribution of $135 \mathrm{~L}$ (Waldmeier et al. 2007). The average elimination half-life $\left(t_{1 / 2}\right)$ of aliskiren in healthy volunteers is $24 \mathrm{~h}$. Plasma steady-state concentrations are achieved in approximately 5-8 days (Pool 2007). Aliskiren is eliminated primarily by biliary/feces excretion ( $77.5 \%$ of the dose), followed by renal excretion $(0.4 \%$ of the oral dose) and oxidative biotransformation (approximately 1.4\%), mainly via cytochrome P450 3A4 (CYP3A4) (Vaidyanathan et al. 2008). Aliskiren does not induce or inhibit cytochrome P450 enzymes and shows no clinically relevant effects on the pharmacokinetics of their substrates. In addition, aliskiren is a substrate for the efflux transporter P-glycoprotein (P-gp), which plays a role in the hepatobiliary and intestinal excretion of the drug (Waldmeier et al. 2007). Aliskiren appears to be more beneficial in obese and resistant hypertension patients with metabolic disorders than in other patients, for whom it is just another viable option in the armory of clinicians to control blood pressure (Pantzaris et al. 2017). Caution should be taken when administering drugs or juices that inhibit P-gp and CYP3A4 concurrently with aliskiren (Abdelkawy et al. 2016). For example, itraconazole markedly raises aliskiren plasma concentrations, likely by inhibiting P-gp and CYP3A4 enzymes (Tapaninen et al. 2011; Tod et al. 2019).

Statins are hydroxymethyl glutaryl-CoA (HMG-CoA) reductase inhibitors. They decrease total cholesterol, low-density lipoprotein, and triglyceride concentrations while increasing high-density lipoprotein concentrations. The primary use of these agents is primary and secondary prevention of coronary artery disease. Pleiotropic effects of statins on endothelial dysfunction are another promising therapeutic use (El-Sisi et al. 2013). Available statins differ in terms of lipid solubility, half-life, and hepatic and renal clearance. Statins are metabolized extensively by the cytochrome P450 (CYP) system (Ballantyne et al. 2003). Atorvastatin selectively and competitively inhibits HMG-CoA reductase (Jacobsen et al. 2000). Atorvastatin is metabolized by CYP3A4 and cellular membrane transport by P-gp, and drug-drug interactions with potent inhibitors of these systems, such as itraconazole, erythromycin, and grapefruit juice, have been demonstrated. Moreover, atorvastatin inhibits P-gp, as indicated by increases in digoxin bioavailability (Prueksaritanont et al. 2002). Furthermore, atorvastatin and ezetimibe downregulate the expression of P-gp in vitro (Abbasi et al. 2016).

Lovastatin is a pro-drug that is activated in vivo by hydrolysis of the lactone ring to form $\beta$-hydroxyacid. The hydrolyzed ring mimics the tetrahedral intermediate produced by the reductase, allowing the agent to bind to HMG-CoA reductase at an affinity 20,000 times greater than its natural substrate (Bizukojc \& Ledakowicz 2007). Lovastatin is both a substrate and inhibitor of cytochrome P450 isoform 3A4 and P-gp. Chong et al. (2014) showed that lovastatin significantly increased the area under the curve (AUC) and peak plasma concentration $\left(\mathrm{C}_{\max }\right)$ of verapamil, a substrate of both CYP enzymes and P-gp in rats. Lovastatin increases the antiproliferative activity of cisplatin against the growth of colorectal cancer cells owing to the inhibition of P-gp pump activity (Sameer 2019).

Data from preclinical and clinical studies suggest new paradigms for statin use in primary cardiovascular disease prevention. Because hypertension contributes to a high risk of cardiovascular morbidity and mortality, the use of statins has been recommended in hypertensive patients (StruijkerBoudier 2017). In addition, both aliskiren and statins (atorvastatin or lovastatin) are metabolized by CYP3A4 and transported by P-gp. This increases the likelihood of pharmacokinetic drug interactions between aliskiren and these statins, but limited data are available regarding such interactions (Lee et al. 2010), and further research is required. This study aims to evaluate and compare the effects of atorvastatin or lovastatin on the pharmacokinetics of aliskiren in rats. 


\section{MATERIALS AND METHODS}

\section{CHEMICALS AND REAGENTS}

Standards (purity $\geq 98 \%$ ) for aliskiren, atorvastatin, lovastatin, and atorvastatin-d5 were purchased from Sigma Aldrich, U.S.A. Aliskiren tablets (Rasilez, Novartis Pharma, Basle, Switzerland), atorvastatin tablets (Lipitor, Pfizer Egypt S.A.E., Cairo, A.R.E under authority of Pfizer INC., U.S.A.), and lovastatin tablets (Lovastmad, Mash For Pharmaceutical Industries \& Cosmetics, Badr City, Egypt) were purchased from the local market.

\section{ANIMALS}

Ninety healthy female albino rats (7-9 weeks old) were obtained from a licensed breeder. All animals were maintained under controlled housing conditions of light and temperature $\left(25^{\circ} \mathrm{C}\right)$ and received standard laboratory feed and water. All rats were allowed at least 2 weeks to acclimate to the conditions before use in experiments. All procedures were approved by the national ethical committee of the College of Veterinary Medicine, Kafrelsheikh University, Egypt. Rats were randomly divided into 3 groups. All three groups were administrated aliskiren by oral gavage at a dose of $8.57 \mathrm{mg} / \mathrm{kg}$ daily for 14 days. Group 2 also received atorvastatin at a dose of $1.143 \mathrm{mg} / \mathrm{kg}$ for 7 days (from day 8 until day 14). Group 3 also received lovastatin at a dose of $1.143 \mathrm{mg} / \mathrm{kg}$ for 7 days (from day 8 until day 14). The study design and flow are shown in Figure 1.

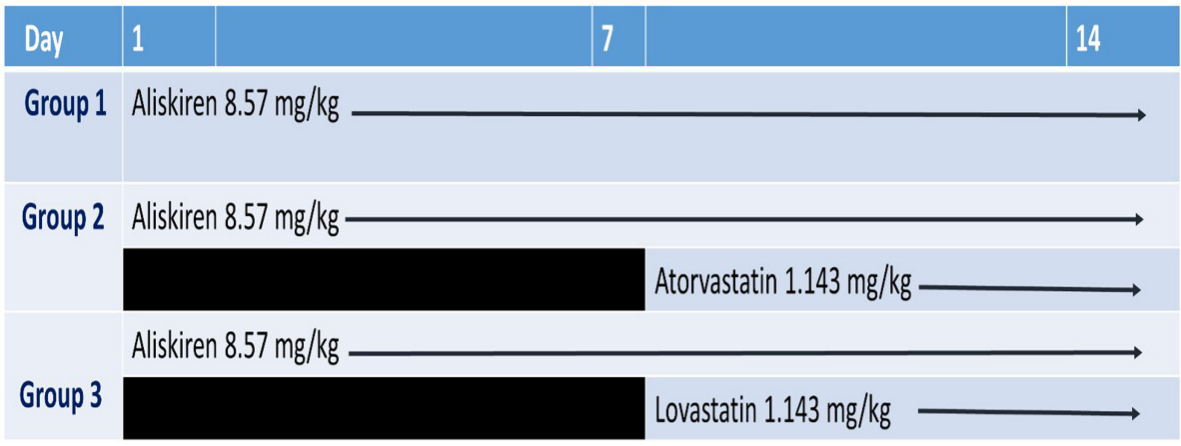

FIGURE 1. Schematic of the study design

\section{PHARMACOKINETIC STUDY}

After the last dose on day 14, an aliquot of approximately $400 \mu \mathrm{L}$ of blood was collected from the retro-orbital vein according to a specific schedule ( 3 animals per time point) of $0,0.25,0.5,1,2,3,6,12,18$, and $24 \mathrm{~h}$ after dosing. The blood samples were transferred immediately to heparinized tubes and centrifuged at $4000 \mathrm{rpm}$ for 10 min. The separated plasma was frozen at $-20^{\circ} \mathrm{C}$ before the assay. Aliskiren concentrations were measured using liquid chromatography-tandem mass spectrometry (LC-MS/MS) as previously reported (Burckhardt et al. 2013) with slight modifications as described below. An atorvastatin-d5 labeled isotope was used as an internal standard.

\section{LC-MS/MS ANALYSIS}

Briefly, each plasma sample $(250 \mu \mathrm{L})$ was spiked with 25 $\mu \mathrm{L}$ of $500 \mathrm{ng} / \mathrm{mL}$ atorvastatin-d5 (IS), and vortexed for $10 \mathrm{~s}$. Protein precipitation was then carried out by adding $1.5 \mathrm{~mL}$ of acetonitrile and samples were homogenized by vortex mixing for 5 min followed by centrifugation at 5,000 rpm for $10 \mathrm{~min}$. After centrifugation, $50 \mu \mathrm{L}$ of the supernatant was transferred to a high-performance liquid chromatography vial and an aliquot of $10 \mu \mathrm{L}$ was injected into the LC-MS/MS system for analysis. The chromatography equipment consisted of an Agilent 1260 Series quaternary pump, column oven, and degasser connected to a thermostat-equipped autosampler. The nebulizer gas was air (zero grade), and nitrogen was used 
as the auxiliary, curtain, and collision gas. The source/ gas-dependent parameters for aliskiren determination were: curtain gas, 40 psi; collision gas, 12 psi; medium temperature, $650{ }^{\circ} \mathrm{C}$; ion spray voltage, $2,000 \mathrm{~V}$; ion source gas one, $40 \mathrm{psi}$; and gas two, $40 \mathrm{psi}$. The mass spectrometer was an AB Sciex Model API 4000. Ion polarity was set in a positive mode, and the source was Turbo Ion Spray. Chromatographic separation was achieved with column C8 $(5 \mu \mathrm{m}, 4.6 \times 50 \mathrm{M}$; Kinetex) and an isocratic elution using a mobile phase composed of $0.1 \%$ formic acid:methanol $(35: 65, \mathrm{v} / \mathrm{v})$. The flow rate was set at $0.7 \mathrm{~mL} / \mathrm{min}$. The column temperature was maintained at $30{ }^{\circ} \mathrm{C}$ with an injection volume of $10 \mu \mathrm{L}$.

\section{ASSESSMENT OF PHARMACOKINETIC PARAMETERS}

Plasma concentration-time profiles of aliskiren were analyzed by a non-compartmental method using WinNonlin 5.0.1 software (v 6.1; Pharsight Corporation, Mountain View, CA, USA). Pharmacokinetic values for $\mathrm{C}_{\max }$ and time to $\mathrm{C}_{\max }\left(\mathrm{T}_{\max }\right)$ were elucidated directly from the observed data. The terminal elimination rate constant (ke) was determined by log-linear regression of at least 3 data points judged in the terminal phase. Values for $t_{1 / 2}$ were determined from the elimination rate constant using the equation $(0.693 / \mathrm{k})$. The AUC from time zero to infinity $\left(\mathrm{AUC}_{0-\infty}\right)$ was determined by the trapezoidal method for the detected values and subsequent extrapolation to infinity. The apparent oral clearance (CL/F) was obtained as dose $/ \mathrm{AUC}_{0-\infty}$.

\section{STATISTICAL ANALYSIS}

Statistical analysis was conducted using GraphPad Prism 5.0 (GraphPad Software Inc., San Diego, CA, USA). Statistical comparisons of the estimated pharmacokinetic values were performed using analysis of variance with Tukey test. All the data were presented as mean \pm standard deviation and a $P$-value $<0.05$ was considered significant.

\section{RESULTS AND DISCUSSION}

\section{PHARMACOKINETICS OF ALISKIREN}

Plasma concentrations of aliskiren were determined using the validated LC-MS/MS. The retention times for aliskiren and the internal standard (atorvastatin-d5) were 1.12 and $2.97 \mathrm{~min}$, respectively, as shown in Figure 2. The mean plasma concentration-time profiles of aliskiren with and without co-administration of atorvastatin and/or lovastatin are presented in Figure 3. The pharmacokinetic parameters of aliskiren are summarized in Table 1. According to recent guidelines, concurrent administration of antihypertensive agents and HMGCoA reductase inhibitors is common, creating a high potential for pharmacokinetic drug interactions between antihypertensive agents and HMG-CoA reductase inhibitors. This study is the first to investigate the effect of multiple-dose administration of atorvastatin or lovastatin on the pharmacokinetics of aliskiren in rats in an effort to the determine possible underlying mechanisms.

TABLE 1. Changes in aliskiren pharmacokinetic parameters after co-administration with atorvastatin or lovastatin

\begin{tabular}{|c|c|c|c|c|c|c|}
\hline \multirow[b]{2}{*}{ Groups } & \multicolumn{6}{|c|}{ PK parameters $($ mean $\pm \mathrm{SD})$} \\
\hline & $\mathrm{AUC}_{0-\infty}(\mathrm{mg} \cdot \mathrm{h} / \mathrm{L})$ & $\begin{array}{c}\mathrm{Cmax} \\
(\mathrm{mg} / \mathrm{L})\end{array}$ & $\begin{array}{c}\text { Tmax } \\
\text { (h) }\end{array}$ & $\begin{array}{c}\mathrm{k} \\
\left(\mathrm{h}^{-1}\right) \\
\end{array}$ & $\begin{array}{l}\mathrm{t}_{1 / 2} \\
(\mathrm{~h})\end{array}$ & $\mathrm{CL} / \mathrm{F}(\mathrm{L} / \mathrm{h})$ \\
\hline Aliskiren & $885 \pm 42$ & $148.5 \pm 10$ & 0.750 & $0.13 \pm 0.03$ & $5.4 \pm 1.2$ & $0.01 \pm 0.0001$ \\
\hline $\begin{array}{l}\text { Aliskiren }+ \\
\text { atorvastatin }\end{array}$ & $614 \pm 69.5$ & $280.0^{*} \pm 60$ & 0.500 & $0.12 \pm 0.01$ & $5.96 \pm 0.47$ & $0.013 \pm 0.001$ \\
\hline $\begin{array}{l}\text { Aliskiren + } \\
\text { lovastatin }\end{array}$ & $1069 * \pm 142$ & $162 * \pm 5.8$ & 1.000 & $0.08^{*} \pm 0.02$ & $9.2 * \pm 2.4$ & $0.007^{*} \pm 0.0003$ \\
\hline
\end{tabular}

*Significant change from control $(\mathrm{P}<0.05)$, AUC: area under the curve, $\mathrm{C}_{\max }$ : maximum plasma concentration, $\mathrm{T}_{\max }$ : time to reach maximum plasma concentration, $\mathrm{k}$ : elimination rate constant, $\mathrm{t}_{1 / 2}$, elimination half-life, CL: systemic clearance, $\mathrm{F}$ : absolute bioavailability, SD: standard deviation 

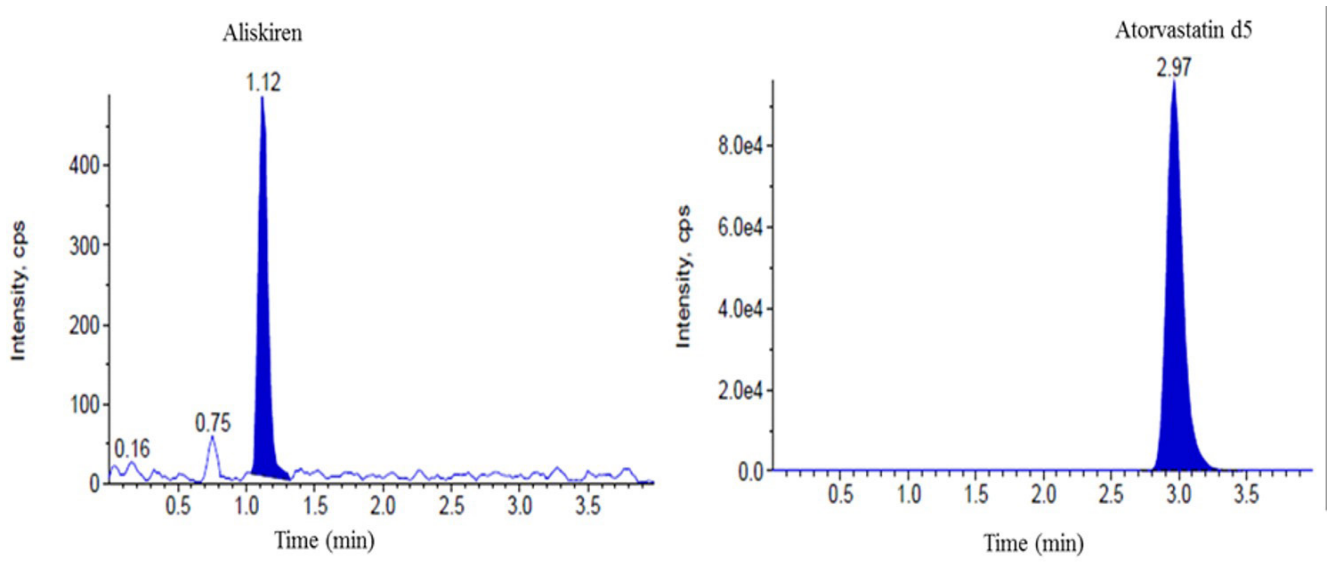

FIGURE 2. LC-MS/MS chromatogram of aliskiren obtained by MRM

(left) and atorvastatin-d5 (internal standard., right)

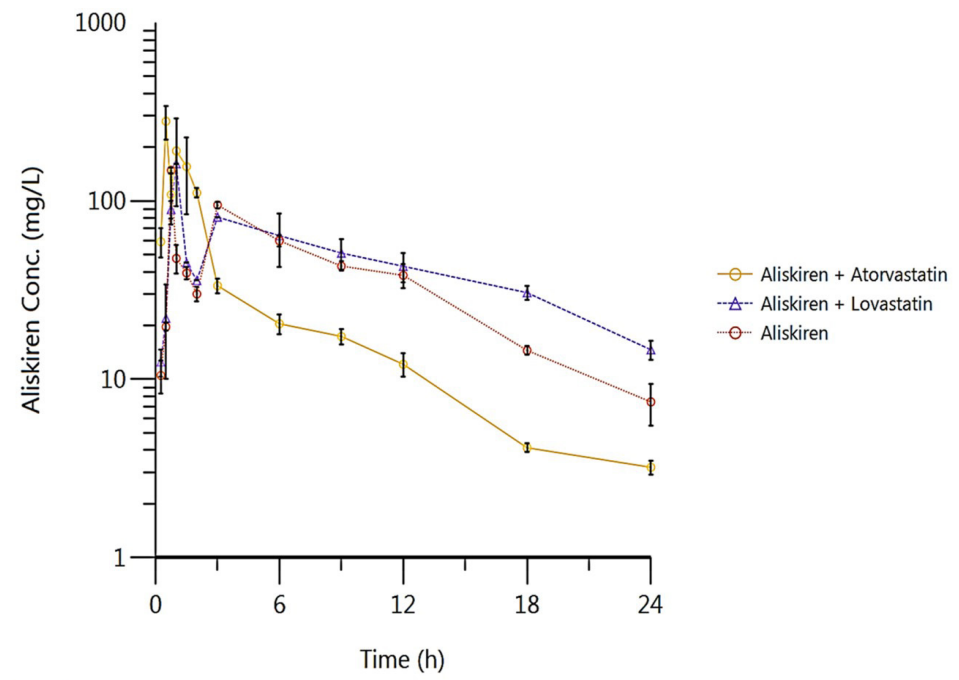

FIGURE 3. Mean \pm SD plasma concentration-time profile of aliskiren with and without co-administration of atorvastatin or lovastatin in rats $(n=3)$

EFFECT OF ATORVASTATIN ON THE PHARMACOKINETICS OF ALISKIREN

Co-treatment with atorvastatin did not significantly alter the rate of absorption of aliskiren, as indicated by nonsignificant changes in $\mathrm{T}_{\max }$. Additionally, except for a $\mathrm{C}_{\max }$ rise of $90 \%$, atorvastatin resulted in non-significant alterations in mean values of the $\mathrm{AUC}_{0-\infty}, \mathrm{t}_{1 / 2}$, and $\mathrm{CL} / \mathrm{F}$ compared with the control. Our findings with atorvastatin support those of other previous studies. For example, no pharmacokinetic interaction was detected between atorvastatin and CYP3A4 substrates such as ximelagatran (Sarich et al. 2004), clopidogrel, and atorvastatin (Saw et al. 2003). Foley-Comer et al. (2011) reported that $C_{\text {max }}$ and the AUC of aleglitazar were not significantly affected by atorvastatin. Also, boceprevir exposure was generally unchanged when co-administered with atorvastatin or pravastatin in healthy volunteers (Hulskotte et al. 2013). Moreover, atorvastatin and fenofibrate exhibited 
no relevant clinical-pharmacokinetic drug interactions (Patiño-Rodríguez et al. 2014). Similarly, atorvastatin had no clinically relevant effect on the pharmacokinetics of raltegravir. The combination was well tolerated and could be administered without dose adjustments (Blonk et al. 2015). Recently, Kashihara et al. (2017) reported that grapefruit juice, but not atorvastatin, reduced the exposure of sulfasalazine, rosuvastatin, glibenclamide, celiprolol, and sumatriptan in healthy volunteers. More recently, McKeand et al. (2018) showed that the $\mathrm{C}_{\max }$ and AUC of bazedoxifene did not change with co-administration of atorvastatin. On the contrary, atorvastatin significantly increased the bioavailability of diltiazem by inhibiting CYP3A4 in rats (Hong et al. 2007). Also, Vats et al. (2012) reported a statistically significant inhibition of cilostazol metabolism using liver microsomes when co-incubated with atorvastatin. Moreover, concurrent administration of atorvastatin and everolimus resulted in a decrease in the $\mathrm{C}_{\max }$ and AUC for the latter by 9 and $5 \%$, respectively, in kidney transplant recipients (Wanitchanont et al. 2014).

In the atorvastatin group, $\mathrm{C}_{\max }$, but not $\mathrm{AUC}$, was significantly elevated, as shown in Table 1 . This phenomenon has been reported before for some drugs. For instance, scopolamine's $\mathrm{C}_{\max }$ was $11 \%$ lower, while its AUC was increased by $35 \%$ in the presence of grapefruit juice (Ebert et al. 2000). From a clinical point of view, the outcome is more a function of the extent of exposure. The AUC is therefore more important to consider compared with the $\mathrm{C}_{\max }$. In practice, longer and lower drug concentration exposure is similarly important, as are shorter but higher concentrations.

\section{EFFECT OF LOVASTATIN ON THE PHARMACOKINETICS OF ALISKIREN}

Oral administration of lovastatin resulted in no observed effect on the rate of absorption of aliskiren, as indicated by non-significant changes in $\mathrm{T}_{\max }$. Compared with control rats, administration of lovastatin resulted in a significant increase in the absorption of aliskiren, as demonstrated by 21 and $10 \%$ increases in the $\mathrm{AUC}_{0-\infty}$ and $\mathrm{C}_{\max }$, respectively. Additionally, lovastatin significantly reduced the $\mathrm{CL} / \mathrm{F}$ by $23 \%$ and increased the $\mathrm{t}_{1 / 2}$ of aliskiren by $72 \%$. These results indicate that lovastatin increased aliskiren bioavailability mainly by inhibiting hepatic liver metabolism. However, this interaction was mild (less than a 2-fold increase in AUC) and resulted in no reported adverse effects. In contrast, atorvastatin was associated with no significant changes in the pharmacokinetics parameters of aliskiren except $\mathrm{C}_{\max }$ values. A possible explanation for this interaction is that lovastatin inhibited the metabolism of aliskiren through the hepatic CYP3A subfamily mainly by enhancing the inhibition of intestinal P-gp and/or the CYP3A subfamily while atorvastatin did not inhibit the hepatic metabolism of aliskiren. From a clinical point of view, the combination of lovastatin and aliskiren should be monitored for any signs of aliskiren toxicity. However, the combination of atorvastatin and aliskiren is considered safe and no monitoring or intervention is required.

A unique feature of this study is the use of the maximum recommended daily doses of atorvastatin, lovastatin, and aliskiren for interactive evaluation. The maximum daily doses helped explore the potential effect of expected interactions and determine if significant toxicity (morbidity or mortality) in rats was present, given that aliskiren exhibits linear pharmacokinetics (Sakaeda et al. 2006). This study employed a multipledose regimen and measured aliskiren concentrations under steady-state conditions. The plasma concentrationtime curve of aliskiren showed a distinctive double peak, indicating possible enterohepatic recirculation. This phenomenon has been reported previously in human subjects (Vaidyanathan et al. 2008).

Our findings are in agreement with many previous studies that found lovastatin inhibited the presystemic metabolism of verapamil in the liver and gastrointestinal tract, and enhanced the AUC of verapamil by a factor of 1.8 (Choi et al. 2010). Furthermore, lovastatin (0.3 and $1.0 \mathrm{mg} / \mathrm{kg}$ ) significantly enhanced the AUC and $\mathrm{C}_{\max }$ of diltiazem in rats, and increased diltiazem bioavailability by inhibiting the CYP3A4-mediated hepatic metabolism (Hong et al. 2011). More recently, Wang et al. (2018) reported that lovastatin inhibited the liver metabolism of sinomenine (a commonly used analgesic in China) in rat liver microsomes and a single dose of lovastatin increased the AUC of sinomenine by a factor of 1.5 and decreased clearance by $65.44 \%$ in rats. However, Hong et al. (2009) reported that lovastatin increased the AUC and $\mathrm{C}_{\max }$ of verapamil by $26-65 \%$ and $34-66 \%$, respectively, without affecting the $\mathrm{T}_{\max }$ and $\mathrm{t}_{1 / 2}$ of verapamil. The authors attributed these effects to inhibition of the verapamil metabolism in the intestine by both theCYP3A-mediated metabolism and P-gp transport. In addition, Chung et al. (2010) reported that lovastatin $(0.3$ and $1 \mathrm{mg} / \mathrm{kg})$ did not affect the AUC bolus of nicardipine after intravenous administration. However, after oral intake of nicardipine with lovastatin, the AUC of nicardipine was $67.4 \%$ greater, and nicardipine oral bioavailability was increased by $38.5 \%$, suggesting that lovastatin did not inhibit the metabolism of nicardipine by the hepatic CYP3A subfamily, but inhibited intestinal P-gp and/or the CYP3A subfamily (Chung et al. 2010). 
Although this is the first report to describe the pharmacokinetic effects of atorvastatin and lovastatin on aliskiren, certain limitations of the study should be considered. First, the concentrations of atorvastatin and lovastatin were not measured because aliskiren is not an inhibitor of P-gp or CYP3A4 metabolism in vivo (Vaidyanathan et al. 2008); therefore, we focused on evaluating the effect of statins on the pharmacokinetics of aliskiren. In addition, future studies may need to increase the number of rats and the duration of drug administration. Despite these limitations, our study showed preliminary evidence for significant effects of lovastatin but not of atorvastatin on aliskiren pharmacokinetics.

\section{CONCLUSION}

Lovastatin induced a prominent increase in aliskiren bioavailability. This increase in aliskiren bioavailability can be attributed to the inhibitory effect of lovastatin on aliskiren metabolism primarily through the hepatic CYP3A subfamily with a minor effect on inhibition of intestinal P-gp and/or the CYP3A subfamily. Caution should be taken when administering lovastatin and aliskiren concurrently, while concurrent atorvastatin and aliskiren administration poses no issues in clinical practice.

\section{REFERENCES}

Abbasi, M., Valizadeh, H., Ham-ishekar, H., Amirkhiz, M.B. \& Milani, P.Z. 2016. In vitro and in situ effects of atorvastatin and ezetimibe on P-glycoprotein expression and function. Bangladesh Journal of Pharmacology 11(4): 911-919.

Abdelkawy, K.S., Donia, A.M., Turner, R.B. \& Elbarbry, F. 2016. Effects of lemon and seville orange juices on the pharmacokinetic properties of sildenafil in healthy subjects. Drugs in $R \& D$ 16(3): 271-278.

Ballantyne, C.M., Corsini, A., Davidson, M.H., Holdaas, H., Jacobson, T.A., Leitersdorf, E., März, W., Reckless, J.P. \& Stein, E.A. 2003. Risk for myopathy with statin therapy in high-risk patients. Archives of Internal Medicine 163(5): 553-564.

Benjamin, E.J., Blaha, M.J., Chiuve, S.E., Cushman, M., Das, S.R., Deo, R., de Ferranti, S.D., Floyd, J., Fornage, M., Gillespie, C., Isasi, C.R., Jiménez, M.C., Jordan, L.C., Judd, S.E., Lackland, D., Lichtman, J.H., Lisabeth, L., Liu, S., Longenecker, C.T., Mackey, R.H., Matsushita, K., Mozaffarian, D., Mussolino, M.E., Nasir, K., Neumar, R.W., Palaniappan, L., Pandey, D.K., Thiagarajan, R.R., Reeves, M.J., Ritchey, M., Rodriguez, C.J., Roth, G.A., Rosamond, W.D., Sasson, C., Towfighi, A., Tsao, C.W., Turner, M.B., Virani, S.S., Voeks, J.H., Willey, J.Z., Wilkins, J.T., Wu, J.H., Alger, H.M., Wong, S.S., Muntner, P. \& American Heart Association Statistics Committee and Stroke Statistics Subcommittee. 2017. Heart disease and stroke statistics-2017 update: A report from the American Heart Association. Circulation 135(10): e146-e603.
Bizukojc, M. \& Ledakowicz, S. 2007. A macrokinetic modelling of the biosynthesis of lovastatin by Aspergillus terreus. Journal of Biotechnology 130(4): 422-435.

Blonk, M., van Beek, M., Colbers, A., Schouwenberg, B. \& Burger, D. 2015. Pharmacokinetic drug-drug interaction study between raltegravir and atorvastatin $20 \mathrm{mg}$ in healthy volunteers. Journal of Acquired Immune Deficiency Syndromes 69(1): 44-51.

Burckhardt, B.B., Ramusovic, S., Tins, J. \& Laeer, S. 2013. Determination of aliskiren in human serum quantities by HPLC-tandem mass spectrometry appropriate for pediatric trials. Biomedical Chromatography: BMC 27(4): 477-486.

Choi, D.H., Chung, J.H. \& Choi, J.S. 2010. Pharmacokinetic interaction between oral lovastatin and verapamil in healthy subjects: Role of P-glycoprotein inhibition by lovastatin. European Journal of Clinical Pharmacology 66(3): 285-290.

Chung, J.W., Yang, S.H. \& Choi, J.S. 2010. Effects of lovastatin on the pharmacokinetics of nicardipine in rats. Biopharmaceutics and Drug Disposition 31(7): 436-441.

Ebert, U., Oertel, R. \& Kirch, W. 2000. Influence of grapefruit juice on scopolamine pharmacokinetics and pharmacodynamics in healthy male and female subjects. International Journal of Clinical Pharmacology and Therapeutics 38(11): 523-531.

El-Sisi, A.A., Hegazy, S.K., Salem, K.A. \& AbdElkawy, K.S. 2013. Atorvastatin improves erectile dysfunction in patients initially irresponsive to sildenafil by the activation of endothelial nitric oxide synthase. International Journal of Impotence Research 25(4): 143-148.

Foley-Comer, A.J., Young, A.M., Russell-Yarde, F. \& Jordan, P. 2011. Aleglitazar, a balanced PPAR $\alpha / \gamma$ agonist, has no clinically relevant pharmacokinetic interaction with high-dose atorvastatin or rosuvastatin. Expert Opinion on Investigational Drugs 20(1): 3-12.

Guo, Y., Zeng, J., Li, Q., Li, P., Luo, F.M., Zhang, W.Z., Lu, Y.X., Wang, Q., Zhang, W., Zeng, Z.P. \& Liu, L.S. 2020. Preliminary clinical study of direct renin inhibitor aliskiren in the treatment of severe COVID-19 patients with hypertension. Zhonghua Nei Ke Za Zhi 59: E011.

Hong, S.P., Yang, J.S., Han, J.Y., Ha, S.I., Chung, J.W., Koh, Y.Y., Chang, K.S. \& Choi, D.H. 2011. Effects of lovastatin on the pharmacokinetics of diltiazem and its main metabolite, desacetyldiltiazem, in rats: possible role of cytochrome P450 3A4 and P-glycoprotein inhibition by lovastatin. Journal of Pharmacy and Pharmacology 63(1): 129-135.

Hong, S.P., Chang, K.S., Koh, Y.Y., Choi, D.H. \& Choi, J.S 2009. Effects of lovastatin on the pharmacokinetics of verapamil and its active metabolite, norverapamil in rats: Possible role of P-glycoprotein inhibition by lovastatin. Archives of Pharmacal Research 32(10): 1447-1452.

Hong, S.P., Chang, K.S., Choi, D.H. \& Choi, J.S. 2007. Effect of atorvastatin on the pharmacokinetics of diltiazem and its main metabolite, desacetyldiltiazem, in rats. Archives of Pharmacal Research 30(1): 90-95.

Hulskotte, E.G., Feng, H.P., Xuan, F., Gupta, S., van Zutven, M.G., O’Mara, E., Wagner, J.A. \& Butterton, J.R. 2013. Pharmacokinetic evaluation of the interaction between 
hepatitis $\mathrm{C}$ virus protease inhibitor Boceprevir and 3-hydroxy-3-methylglutaryl coenzyme A reductase inhibitors atorvastatin and pravastatin. Antimicrobial Agents and Chemotherapy 57(6): 2582-2588.

Jacobsen, W., Kuhn, B., Soldner, A., Kirchner, G., Sewing, K.F., Kollman, P.A., Benet, L.Z. \& Christians, U. 2000. Lactonization is the critical first step in the disposition of the 3-hydroxy-3-methylglutaryl-CoA reductase inhibitor atorvastatin. Drug Metabolism and Disposition: The Biological Fate of Chemicals 28(11): 1369-1378.

Kashihara, Y., Ieiri, I., Yoshikado, T., Maeda, K., Fukae, M., Kimura, M., Hirota, T., Matsuki, S., Irie, S., Izumi, N., Kusuhara, H. \& Sugiyama, Y. 2017. Small-dosing clinical study: Pharmacokinetic, pharmacogenomic (SLCO2B1 and $\mathrm{ABCG} 2$ ), and interaction (atorvastatin and grapefruit juice) profiles of 5 probes for OATP2B1 and BCRP. Journal of Pharmaceutical Sciences 106(9): 2688-2694.

Lee, C.K., Choi, J.S. \& Choi, D.H. 2015. Effects of HMG-CoA reductase inhibitors on the pharmacokinetics of nifedipine in rats: Possible role of P-gp and CYP3A4 inhibition by HMG-CoA reductase inhibitors. Pharmacological Reports 67(1): 44-51.

McKeand, W., Baird-Bellaire, S., Ermer, J. \& Patat, A. 2018. A study of the potential interaction between Bazedoxifene and atorvastatin in healthy postmenopausal women. Clinical Pharmacology in Drug Development 7(8): 911-919.

Merai, R., Siegel, C., Rakotz, M., Basch, P., Wright, J., Wong, B., Thorpe, P.DHSc. \& Thorpe, P. 2016. CDC grand rounds: A public health approach to detect and control hypertension. MMWR. Morbidity and Mortality Weekly Report 65(45): 1261-1264.

Mourad, J. \& Levy, B.I. 2020. Interaction between RAAS inhibitors and ACE2 in the context of COVID-19. Nature Reviews Cardiology 17(5): 313-313.

Omar, A. 2020. Molecular docking reveals the potential of aliskiren, dipyridamole, mopidamol, rosuvastatin, rolitetracycline and metamizole to inhibit COVID-19 virus main protease. Chemrxiv. Preprint.

Pantzaris, N., Karanikolas, E., Tsiotsios, K. \& Velissaris, D. 2017. Renin inhibition with aliskiren: A decade of clinical experience. Journal of Clinical Medicine 6(6): 61-80.

Patiño-Rodríguez, O., Torres-Roque, I., Martínez-Delgado, M., Escobedo-Moratilla, A. \& Pérez-Urizar, J. 2014. Pharmacokinetic non-interaction analysis in a fixed-dose formulation in combination of atorvastatin and ezetimibe. Frontiers in Pharmacology 5(261): 1-9.

Pool, J.L. 2007. Direct renin inhibition: Focus on aliskiren. Journal of Managed Care Pharmacy 13(8)(Supp B): 21-33.

Prueksaritanont, T., Tang, C., Qiu, Y., Mu, L., Subramanian, R. \& Lin, J.H. 2002. Effects of fibrates on metabolism of statins in human hepatocytes. Drug Metabolism and Disposition: The Biological Fate of Chemicals 30(11): 1280-1287.

Sakaeda, T., Fujino, H., Komoto, C., Kakumoto, M., Jin, J.S., Iwaki, K., Nishiguchi, K., Nakamura, T., Okamura, N. \& Okumura, K. 2006. Effects of acid and lactone forms of eight HMG-CoA Reductase Inhibitors on CYP-mediated metabolism and MDR1-mediated transport. Pharmaceutical Research 23(3): 506-512.

Sameer, E. 2019. Potentiation of cisplatin activity in colorectal cancer cells by lovastatin. Journal of Pharmaceutical Research International 28(1): 1-6.

Sarich, T.C., Schützer, K.M., Dorani, H., Wall, U., Kalies, I., Ohlsson, L. \& Eriksson, U.G. 2004. No pharmacokinetic or pharmacodynamic interaction between atorvastatin and the oral direct thrombin inhibitor ximelagatran. Journal of Clinical Pharmacology 44(8): 928-934.

Saw, J., Steinhubl, S.R., Berger, P.B., Kereiakes, D.J., Serebruany, V.L., Brennan, D., Topol, E.J. \& Clopidogrel for the Reduction of Events During Observation Investigators. 2003. Lack of adverse clopidogrel-atorvastatin clinical interaction from secondary analysis of a randomized, placebo-controlled clopidogrel trial. Circulation 108(8): 921-924.

Struijker-Boudier, H. 2017. Should a statin be given to all hypertensive patients? Artery Research 18(C): 66-68.

Tapaninen, T., Backman, J.T., Kurkinen, K.J., Neuvonen, P.J. \& Niemi, M. 2011. Itraconazole, a P-glycoprotein and CYP3A4 inhibitor, markedly raises the plasma concentrations and enhances the renin-inhibiting effect of aliskiren. Journal of Clinical Pharmacology 51(3): 359-367.

Tod, M., Goutelle, S., Bleyzac, N. \& Bourguignon, L. 2019. A generic model for quantitative prediction of interactions mediated by efflux transporters and cytochromes: Application to p-glycoprotein and cytochrome 3A4. Clinical Pharmacokinetics 58(4): 503-523.

Vaidyanathan, S., Jarugula, V., Dieterich, H.A., Howard, D. \& Dole, W.P. 2008. Clinical pharmacokinetics and pharmacodynamics of aliskiren. Clinical Pharmacokinetics 47(8): 515-531.

Vats, R., Varanasi, K.V., Arla, R., Veeraraghvan, S. \& Rajak, S. 2012. Drug-drug interaction study to assess the effects of atorvastatin co-administration on pharmacokinetics and anti-thrombotic properties of cilostazol in male Wistar rats. Biopharmaceutics and Drug Disposition 33(8): 455-465.

Waldmeier, F., Glaenzel, U., Wirz, B., Oberer, L., Schmid, D., Seiberling, M., Valencia, J., Riviere, G.J., End, P. \& Vaidyanathan, S. 2007. Absorption, distribution, metabolism, and elimination of the direct renin inhibitor aliskiren in healthy volunteers. Drug Metabolism and Disposition: The Biological Fate of Chemicals 35(8): 1418-1428.

Wang, Y., Jin, Y., Yun, X., Wang, M., Dai, Y. \& Xia, Y. 2018. Co-administration with simvastatin or lovastatin alters the pharmacokinetic profile of sinomenine in rats through cytochrome P450-mediated pathways. Life Sciences 209: 228-235.

Wanitchanont, A., Somparn, P., Vadcharavivad, S., Chancharoenthana, W., Townamchai, N., Praditpornsilpa, K. \& Avihingsanon, Y. 2014. Effects of atorvastatin on the pharmacokinetics of everolimus among kidney transplant recipients. Transplantation Proceedings 46(2): 418-421.

Wood, J.M., Maibaum, J., Rahuel, J., Grütter, M.G., Cohen, N.C., Rasetti, V., Rüger, H., Göschke, R., Stutz, S., Fuhrer, W., Schilling, W., Rigollier, P., Yamaguchi, Y., Cumin, F., Baum, 
H.P., Schnell, C.R., Herold, P., Mah, R., Jensen, C., O’Brien, E., Stanton, A. \& Bedigian, M.P. 2003. Structure-based design of aliskiren, a novel orally effective renin inhibitor. Biochemical and Biophysical Research Communications 308(4): 698-705.

Yoon, S.S., Carroll, M.D. \& Fryar, C.D. 2015. Hypertension prevalence and control among adults: United States, 20112014. NCHS Data Brief 220: 1-8.

Zhao, C., Vaidyanathan, S., Yeh, C.M., Maboudian, M. \& Armin Dieterich, H. 2006. Aliskiren exhibits similar pharmacokinetics in healthy volunteers and patients with Type 2 diabetes mellitus. Clinical Pharmacokinetics 45(11): 1125-1134.

Amal Sharaf, Kamal A. El-Shazly, Amera Abd El Latif \& Hazim O. Khalifa*

Department of Pharmacology

Faculty of Veterinary Medicine

Kafrelsheikh University

Kafr El-Sheikh

33516 Egypt
Khaled S. Abdelkawy

Faculty of Pharmacy

Kafrelsheikh University

Kafr El-Sheikh

33516 Egypt

Fawzy Elbarbry

School of Pharmacy

Pacific University

Hillsboro OR

97123 USA

Hazim O. Khalifa*

Department of Infectious Diseases

Graduate School of Medicine

International University of Health and Welfare

Narita 286-8686

Japan

*Corresponding author; email: hazem.khalifa1@vet.kfs.edu.eg

Received: 28 May 2020

Accepted: 7 August 2020 